\title{
Death seasonality determination from pinnipeds teeth: the Cueva del Negro site case (Argentine Patagonia)
}

\section{( Pablo Ambrústolo*, Miguel A. Zubimendi" and Enrique Crespo**:}

Recibido:

6 de marzo de 2018

Aceptado:

21 de agosto de 2018

\begin{abstract}
In this article, we present the first results of the determination of season at death performed over eighteen South American sea lions (Otaria flavescens) teeth recovered at Cueva del Negro site (northern coast of the Santa Cruz Province, Patagonia, Argentina). Age and season of death were determined by growth-layer analysis on sea lion teeth. This analysis allowed us to suggest potential aboriginal hunting strategies regarding the capture of these pinnipeds. Our results indicate that sea lions were hunted between summer and early fall, more precisely between January and April. This would reflect a marked seasonality in relation to sea lion availability, which could be explained in terms of mobility and subsistence strategies of the human groups that inhabited the area. In this sense, our results are discussed taking into consideration paleodietary data and the existing archaeological studies.
\end{abstract}

\section{Determinación de estacionalidad de muerte en dientes de pinnípedos: el caso del sitio Cueva del Negro (Patagonia Argentina)}

\section{Keywords}

Otaria flavescens Seasonality Patagonia Hunter-gatherers Coastal occupations

\section{Resumen}

En este trabajo se presentan los primeros resultados de los estudios de estacionalidad de muerte obtenidos sobre 18 dientes de pinnípedos (Otaria flavescens) recuperados en el sitio Cueva del Negro (costa norte de la provincia de Santa Cruz, Patagonia Argentina). Los mencionados análisis nos permitieron plantear un potencial patrón de captura de dichas presas y forma de uso de un espacio puntual. Las tendencias preliminares sugieren una explotación de pinnípedos orientada hacia el verano e inicios de otoño, más precisamente entre los meses de enero y abril. Ello reflejaría una marcada estacionalidad en relación con el aprovisionamiento de las presas, lo que podría explicarse en función de las estrategias de movilidad y modo de subsistencia de los grupos humanos que habitaron el área. En este sentido, los resultados se discuten en función de información paleodietaria y los antecedentes arqueológicos disponibles.

\section{Palabras clave}

Otaria flavescens Estacionalidad Patagonia

Cazadores-recolectores Ocupaciones costeras 


\section{Introduction}

Archaeological research carried out along the northern coast of the Santa Cruz Province, Argentina, supports the concept of an intensive, seasonal, and variable exploitation of coastal areas and resources by human hunter-gatherer groups, mainly during the Late Holocene to the south of the Deseado Estuary (Ambrústolo, 2011; Castro et al., 2003; Zubimendi, 2010). The archaeological record presents mainly open-air sites, in most cases shell middens on dunes, which contain lithic, bone, and malacological remains (Hammond, 2015). Furthermore, in recent years occupations have been identified in rock-shelters located at different distances from the coast (Ambrústolo and Ciampagna, 2015; Ambrústolo and Zubimendi, 2015). The sites spatial distribution suggests a structured use of the environment, mainly linked to the availability of mollusk banks and pinniped colonies near to a number of coastal areas (Castro et al., 2003).

The archaeological record of the area shows evidence for pinniped exploitation from the initial occupation, dating to the Middle Holocene (Alero El Oriental site, $6930 \pm 100$ years BP, $5810 \pm 110$ years BP, $5860 \pm 90$ years BP, $5810 \pm 110$ years BP) (Ambrústolo, Zubimendi, Ciampagna and Trola, 2011), through to the Late Holocene, mainly between $\mathrm{ca}$. 2000 and 1300 years BP (Ambrústolo and Beretta, 2018; Zubimendi et al., 2011; Zubimendi, Ambrústolo, Zilio and Castro, 2015). Calculations of relative abundance of anatomical sea lion portions identified in rock shelters suggest a trend toward a greater use of the meat associated with the skull, the thoracic region, the first portions of the forelimbs and flippers (Ambrústolo and Beretta, 2018). This was observed on bone assemblages from both adult and juvenile individuals. Juveniles are very strongly represented within the archaeological record.

The pinnipeds commonly present along the Patagonian littoral belong to two species, both of the Otariidae family: the South American fur seal (Arctocephalus australis) and the South American sea lion (Otaria flavescens). The two species have an annual cycle that divides between a short reproductive phase and a period of regular visits to coastal areas (Crespo, García, Dans and Pedraza 2008a; Crespo et al., 2008b). In the case of sea lions (Otaria flavescens), the calving season occurs between late December and mid-February (Crespo, 1988), while fur seals commence their breeding season between December and early January (Schiavini, 1990). During the reproductive phase, two types of colonies are recorded: one of juveniles, without reproductive capacity or activity, and one for breeding, in which a pup's females and adult territorial males predominate (Crespo et al., 2008a and b). After the reproductive phase, the otariids form resting colonies that may, or may not, coincide with the earlier breeding areas.

In these resting colonies, the social structure present varies in terms of the age and sex of the animals represented (Crespo et al., 2008a and b). In general terms, non-territorial adult males and immature individuals are found segregated, so they tend to group into specific settlements, although they have a tendency to stay longer in the water for the purposes of finding food. The females continuously return to the nursery areas to nurse the pups, so their range of mobility is more restricted (Bowen, Beck and Austin, 2009; Crespo et al., 2008a, 2008b). It should be noted that, in general, South American sea lion chooses coasts with smooth and sheltered slopes in which to establish their reproductive and non-reproductive colonies (Crespo et al., 2008b; Schiavini, 1990).

The availability and exploitation strategies of pinnipeds employed by human huntergatherer groups during the Holocene are a subject of constant discussion in studies carried out along the Patagonian coasts. In general, results show that the predator-prey relationship presents some variability depending on factors related to seasonality issues and/or requirements in relation to the type of procurement, the transportation of prey, and the available technology (see among others, Borella, 2016; Cruz et al., 2015; 
Lanata and Borrero, 1994; Lanata and Winograd, 1988; Legoupil, 2003; Martinoli, 2015; Muñoz, 2011; Orquera and Piana, 1999; Schiavini, 1993).

The study of dentine and/or cement deposition patterns in the teeth of marine mammals can be used, not only for estimating the age and reproductive states of the individuals, but also for ecological and behavioral studies (Whitmann et al., 2016). In pinnipeds, the study of the successive layers of dentine and cement of the canine and post-canine teeth has been undertaken on several species: Callorhinus ursinus, Phoca vitulina, Zalophus californianus, Arctocephalus gazella, A. australis, Phoca groenlandica, Halichoerus grypus, Otaria flavescens, Mirounga angustirostris, Lobodon carcinophaga, Hydrurga leptonyx, Leptonychotes weddellii, Mirounga leonina and Arctocephalus pusillus (Loza et al., 2016). Some of the techniques applied include the counting of external rings of the root of the teeth, and the counting of dentine and cement lines with, and without, decalcification processes. We should mention that not all techniques are applicable to all species or to all teeth. In general, the variations depend on the size of the teeth and the way in which the cement is deposited (Loza et al., 2016). Following from this, Loza and collaborators (2016) evaluated the effectiveness of different techniques as applied on teeth to determine the absolute ages of specimens of Phocidae and Otariidae (Mammalia). The results of this study showed that not all techniques had the same effectiveness across all the species studied. The technique for counting dentine lines was effective in the species of the genus Arctocephalus and, to a lesser extent, in Otaria flavescens. In Phocidae, the layer's deposition pattern is very different to those observed in the Otariidae, in these cases, the technique of counting cement lines with previous decalcification presented the most reliable results.

In this paper, we studied the seasonality of death in sea lion teeth collected at the Cueva del Negro site (Figure 1A and B). Based on this analysis we then discussed pinniped exploitation strategies in the context of the hunter-gatherer human groups that occupied the area during the Late Holocene. Here we present the results of measurements of growth layer groups on those teeth.

\section{The pinnipeds exploitation in the Cueva del Negro site}

The Cueva del Negro archaeological site is located to the south of the Deseado Estuary (Figure 1A). The rock shelter is only 20 meters from the modern-day upper tide line of the Atlantic Ocean, and 4 meters above sea level (Zubimendi et al., 2011; Figure 2A). The site's stratigraphic sequence was recorded during the systematic excavation of a surface of $3 \mathrm{~m}^{2}$ over three separate grid squares, located near the access to the refuge. Grid squares 1 and 2 were contiguous and located along the drip line. These two grid squares revealed a dense matrix of remains, mostly composed of mollusk shells, pinniped bones, and lithic artifacts (Figure 2B). Five stratigraphic levels were identified, and a depth of approximately two meters was excavated. Radiocarbon dates indicate that the materials in these grid squares were deposited between $c a$. 1,700 and 1,300 years BP, occupations with chronologies assignable to the Late Holocene (Zubimendi et al., 2011). Grid square 3 was located inside the shelter, at a medium distance between the drip line and the inner wall of the site.

For the purposes of the zooarchaeological studies carried out at the site, only the pinniped bone remains from grid 3 were analyzed in their entirety. Other faunal remains - such as avian - were analyzed from all the three excavated grids. Below, we present the partial results that have emerged from a recent study (Ambrústolo and Beretta, 2018). The bone assemblage is composed by NISP $=1184$, of which 223 are indeterminate fragments. Among the specimens determined $(\mathrm{n}=961)$, mammal bones presented high relative and absolute frequencies $(\mathrm{n}=689,71.7 \%)$; then to a lesser extent, birds (NISP $=258$, $26.8 \%$ ), and fish remains (NISP $=14,1.5 \%$ ) were recorded. Most of mammalian remains are pinnipeds bones $(\mathrm{n}=626,90.8 \%)$. An MNI of eight juvenile individuals and three adults was estimated (Table 1). Most of the specimens belonged to juvenile prey (NISP 


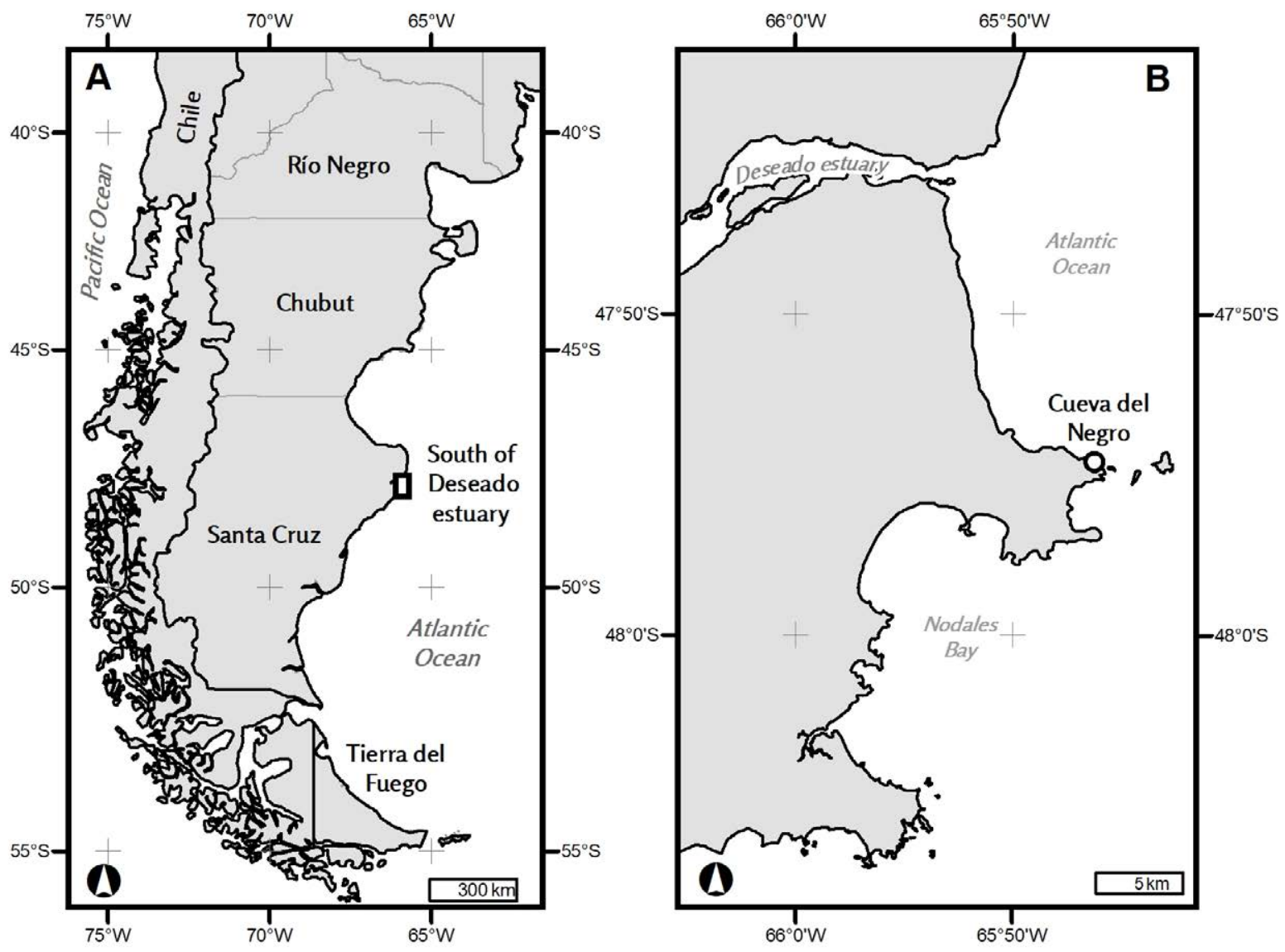

Figure 1. A) South of the Deseado estuary; B) Cueva Del Negro site.

$=478,76 \%)$; only $5.66 \%($ NISP $=35)$ corresponded to adult individuals. In 113 bone elements - skull and rib portions - the relative age could not be determined.

Juvenile/sub-adult pinnipeds were represented in all their skeletal parts, suggesting that the whole individual was being brought onto the site. In general terms, the parts which are most highly represented in terms of percentage are the axial skeleton, especially the skull, the hyoid complex associated with the tongue bones, the vertebrae and the ribs, and some limb bones (in all cases with \%MAU greater than 30). In the case of the upper forelimbs bones: humerus, radius, ulnas and scapholunar are presented in higher percentages. Among the the hindlimb bones, the highest percentages based on the calculation of \%MAU were observed among the pelvis, femur, fibula and tibia (Table 1).

The representation of anatomical units corresponding to adult individuals was fragmentary, which supports the idea that these animals were killed on-location, outside the cave, and then fragmented and transported by parts to the cave site. High proportions of elements corresponding to the skull (including teeth and bones associated with tongue support) and lower jaws (with \%MAU greater than 70) (Table 1) were recorded at the site. In smaller proportions, bones corresponding to the upper forelimb were identified. In effect, we saw the introduction to the site of anatomical portions with a high meat yield (Savelle, Friesen and Lyman, 1996), in this case, mainly the skull and the lower jaws (Table 1).

Anthropic modifications and consumption evidence, suggesting the exploitation of juvenile and adult prey was present on some specimens. In this regard, we should state 

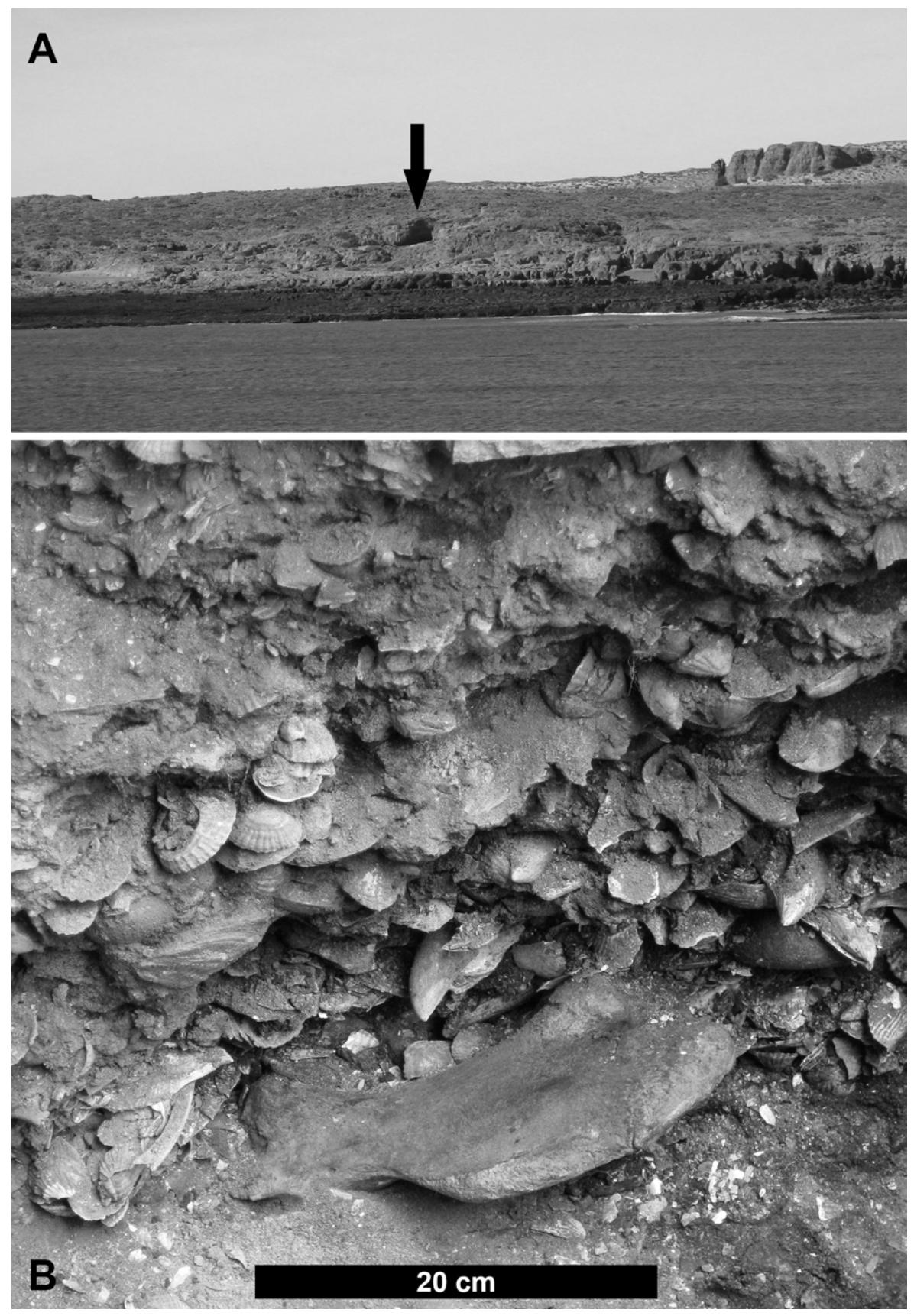

Figure 2. A) View of the entrance of Cueva del Negro site (black arrow); B) view of archaeological context.

that $11 \%(\mathrm{NISP}=67)$ of the bone elements had cutting marks, these were observed mainly on the forelimbs, ribs, and vertebrae. A $1.45 \%$ (NISP = 9) of the remains showed evidence of combustion in association with cut marks. Regarding the location of the latter, studies suggest that they were found mainly on the proximal and distal areas of the diaphysis of bones, this is compatible with activities related to the disarticulation of skeletal portions (Lyman, 1992; Martinoli, 2015). The marks identified on the hyoid apparatus, jaw and the vertebrae apophysis would cogent with de-fleshing activities. On the other hand, those observed in the proximal region of the metacarpals and metatarsals diaphysis would be linked to the extraction of tendons, skinning activities (Cartajena and Labarca, 2007), and the consumption of the adipose panniculus located in the lower region, this last with the purpose of extracting fat and adhering meat (Martinoli, 2015). 


\begin{tabular}{|c|c|c|c|c|c|}
\hline Anatomical units & NISP & MNI & MNE & MAU & \%MAU \\
\hline Skull & 31 & 6 & 6 & 6 & 100 \\
\hline Lower jaw & 2 & 1 & 1 & 0.5 & 8.3 \\
\hline Teeth & 125 & 6 & 6 & 0.2 & 3.3 \\
\hline Hyoid complex & 8 & 2 & 2 & 2 & 33.3 \\
\hline Atlas & 1 & 1 & 1 & 1 & 16.7 \\
\hline Cervical vertebrae & 14 & 3 & 12 & 2.4 & 40.0 \\
\hline Dorsal vertebrae & 33 & 3 & 27 & 1.8 & 30.0 \\
\hline Lumbar vertebrae & 11 & 3 & 11 & 2.2 & 36.7 \\
\hline Sacrum & 1 & 1 & 1 & 1 & 16.7 \\
\hline Coccygeal vertebrae & 7 & 1 & 7 & 0.5 & 8.3 \\
\hline Ribs & 78 & 2 & 58 & 1.9 & 31.7 \\
\hline Sternebrae & 4 & 1 & 4 & 0.6 & 10.0 \\
\hline Scapula & 8 & 3 & 3 & 1.5 & 25.0 \\
\hline Humerus & 5 & 4 & 4 & 2 & 33.3 \\
\hline Radius & 11 & 8 & 9 & 4.5 & 75.0 \\
\hline Ulna & 6 & 3 & 6 & 3 & 50.0 \\
\hline Scapholunar & 5 & 4 & 5 & 2.5 & 41.7 \\
\hline Trapezium & 2 & 2 & 2 & 1 & 16.7 \\
\hline Trapezoid & 1 & 1 & 1 & 0.5 & 8.3 \\
\hline Ganchoso & 1 & 1 & 1 & 0.5 & 8.3 \\
\hline Metacarpal I & 4 & 2 & 4 & 2 & 33.3 \\
\hline Metacarpal II-V & 16 & 3 & 16 & 2 & 33.3 \\
\hline Pelvis & 12 & 8 & 11 & 5.5 & 91.7 \\
\hline Femur & 8 & 6 & 7 & 3.5 & 58.3 \\
\hline Tibia & 5 & 4 & 4 & 2 & 33.3 \\
\hline Fibula & 8 & 5 & 7 & 3.5 & 58.3 \\
\hline Patella & 3 & 2 & 3 & 1.5 & 25.0 \\
\hline Calcaneum & 2 & 1 & 2 & 1 & 16.7 \\
\hline Astragalus & 1 & 1 & 1 & 0.5 & 8.3 \\
\hline Navicular & 1 & 1 & 1 & 0.5 & 8.3 \\
\hline Cuboid & 2 & 2 & 2 & 1 & 16.7 \\
\hline Internal Cuneiform & 1 & 1 & 1 & 0.5 & 8.3 \\
\hline External Cuneiform & 1 & 1 & 1 & 0.5 & 8.3 \\
\hline Metatarsal I & 2 & 1 & 2 & 1 & 16.7 \\
\hline Metatarsal II - IV & 11 & 3 & 11 & 1.4 & 23.3 \\
\hline Phalanges & 47 & 1 & 45 & 0.8 & 13.3 \\
\hline Total & 478 & - & 285 & - & - \\
\hline
\end{tabular}

Table 1. Bone elements of juvenile pinnipeds recorded at the Cueva del Negro site (Grid 3).

\section{Materials and methods: seasonality studies of death in pinnipeds}

The teeth of pinnipeds, as well as those from other marine or terrestrial mammals, are useful for age determination of the individual in question. Depending on the quality of the tooth section, the last group of layers close to the pulp cavity may indicate the 
precise moment of the animal's demise (Crespo, Schiavini, Perez Macri, Reyes and Dans, 1994; Grandi, Dans, Garcia and Crespo, 2010).

Pinniped dental pieces are diagnostic elements in regard to, among other matters, the seasonality or moment of death of the individual. The fact is that the growth of these animals is in part structured by environmental variables, these variables condition modifications that imprint themselves on the dentine and the cement of the animal teeth (Crespo et al., 1994, Grandi et al., 2010). Within this framework, the lines or bands of growth identified in these specimens are generated sequentially and create a development pattern that can be interpreted in terms of the study of a number of interrelated aspects, including among others, the individual's growth and seasonality of death (Crespo, 1988; Grandi et al., 2010; Laws, 1962; Molina-Schiller and Pinedo, 2004; Pretto, 2016; Rosas, Haimovici and Pinedo, 1993; Schiavini, Lima and Batallés, 1992).

From an archaeological perspective, this constitutes an important inferential tool in terms of discussions concerning the predator-prey relationship regarding the capture strategies of the latter. In this sense, we consider that seasonality studies constitute an important tool to understand when, or why, a particular site or area was occupied in the past. In turn, this allows us to discuss certain characteristics of the zooarchaeological assemblages within a framework evaluating human exploitation (see review in Sbovoda, 2013, among others).

Worldwide, various archaeological studies have used determinations of moment of death on some of the prey represented in the bone assemblages. This has been employed in order to generate estimates that can then be cross-related to issues such as capture seasonality and/or the existence of variations in strategies of human mobility in the context of seasonal visits to coastal areas (Monks, 1981; Woodborne, Hart, and Parkington, 1995, among others). Within the framework of studies to determine the age and seasonality of death of prey identified in archaeological contexts from Patagonia, there are currently few existing studies that apply techniques related to the counting of pinniped tooth rings. In this sense, it is worth mentioning that fragmentary data have been presented from specific areas such as the Beagle Channel (Schiavini, 1993), northern Patagonia (Borella, 2016; Serrán, Centeno, Weiler and Gómez Otero, 2008), and a recent study on samples from Punta Entrada, located on mouth of the Santa Cruz River (Pretto, 2016).

Death seasonality analysis of pinnipeds from Cueva del Negro were made on 18 teeth samples recovered from the stratigraphic sequences of grids 1 and $2^{1}$. It should be noted that on the basis of the different stratigraphic levels $(n=5)$ and the associated radiocarbon dates, the determinations of seasonality in the different teeth correspond to 15 individuals. The study was carried out by counting groups of complete (annual) bands of growth layer groups in each of the teeth (Figures 3, 4 and 5). As shown in Table 2 , the pieces of the sample analyzed -in the cases in which they could be determinedbelong to the species Otaria flavescens.

Teeth of adult individuals were cut longitudinally or transversally with a handsaw, polished with sand paper (grain of 400-1,000 microns) and then analyzed under a stereoscopic microscope with transmitted light (Crespo et al., 1994). Macroscopically speaking, the dentine deposition pattern in the South American sea lion involves a wide opaque layer and a thin translucent layer which is deposited during the breeding season. The opaque and the translucent layers correspond chronologically to one year (Crespo, 1988; Laws, 1962). Seasonality was determined as the proportion of the opaque layer deposited next to the last translucent layer and the pulp cavity. This means that if the last layer was a translucent one the animal died during the breeding season. If a quarter of an opaque layer was formed the animal died at the end of summer or early fall
1. The seasonality studies were carried out on samples from the initial excavation of the site (grids 1 and 2). The excavation of grid 3 was undertaken after the studies presented here. 

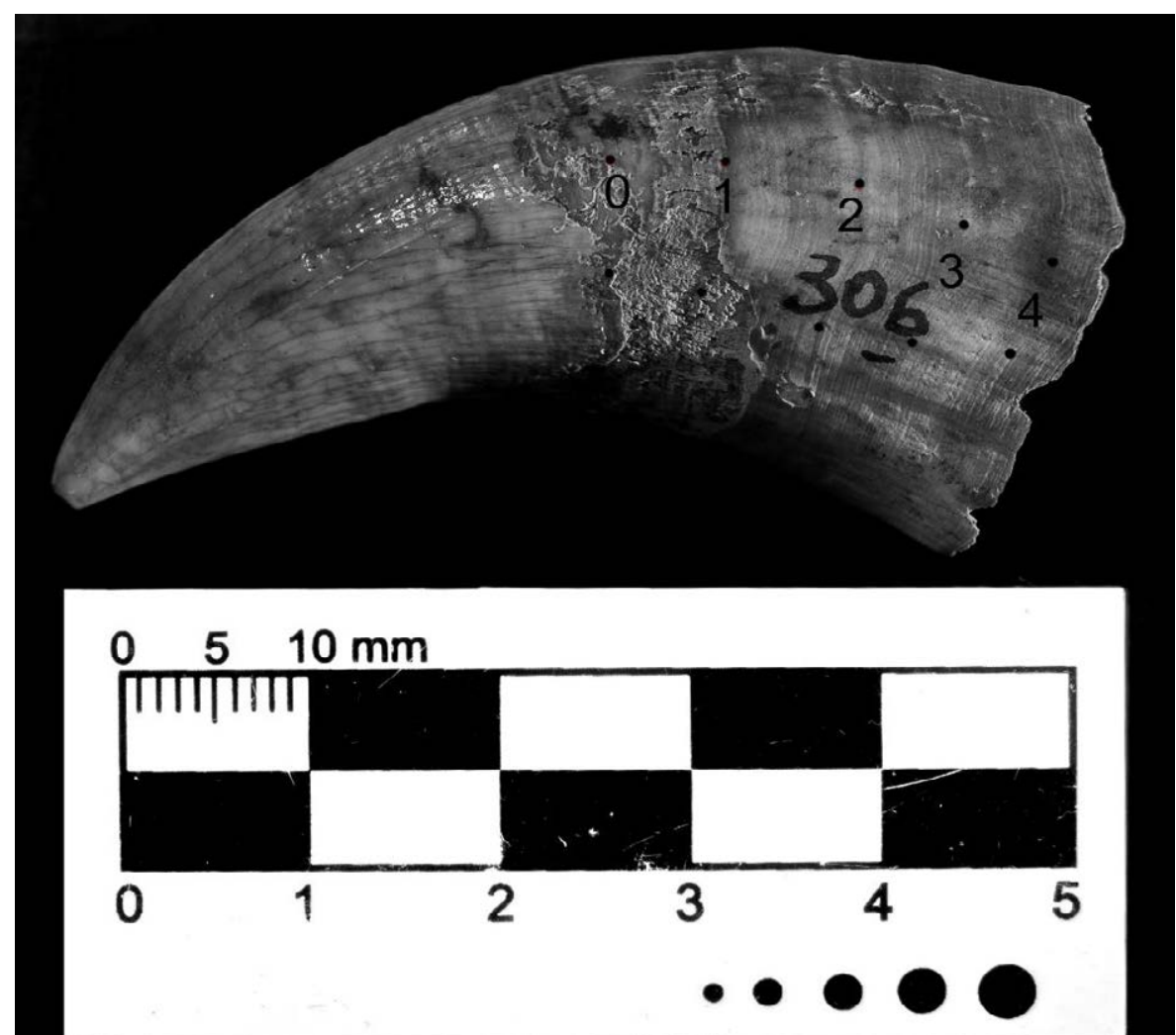

Figure 3. Upper canine teeth of sea lion male, 4 years old ( $C d N-12)$. Increment layers can be counted with the naked eye: $\mathrm{o}$ is the neonatal line, 1 to 4 are layers deposited during the breeding season in January. Additional lines indicate death around the end of summer or early autumn.

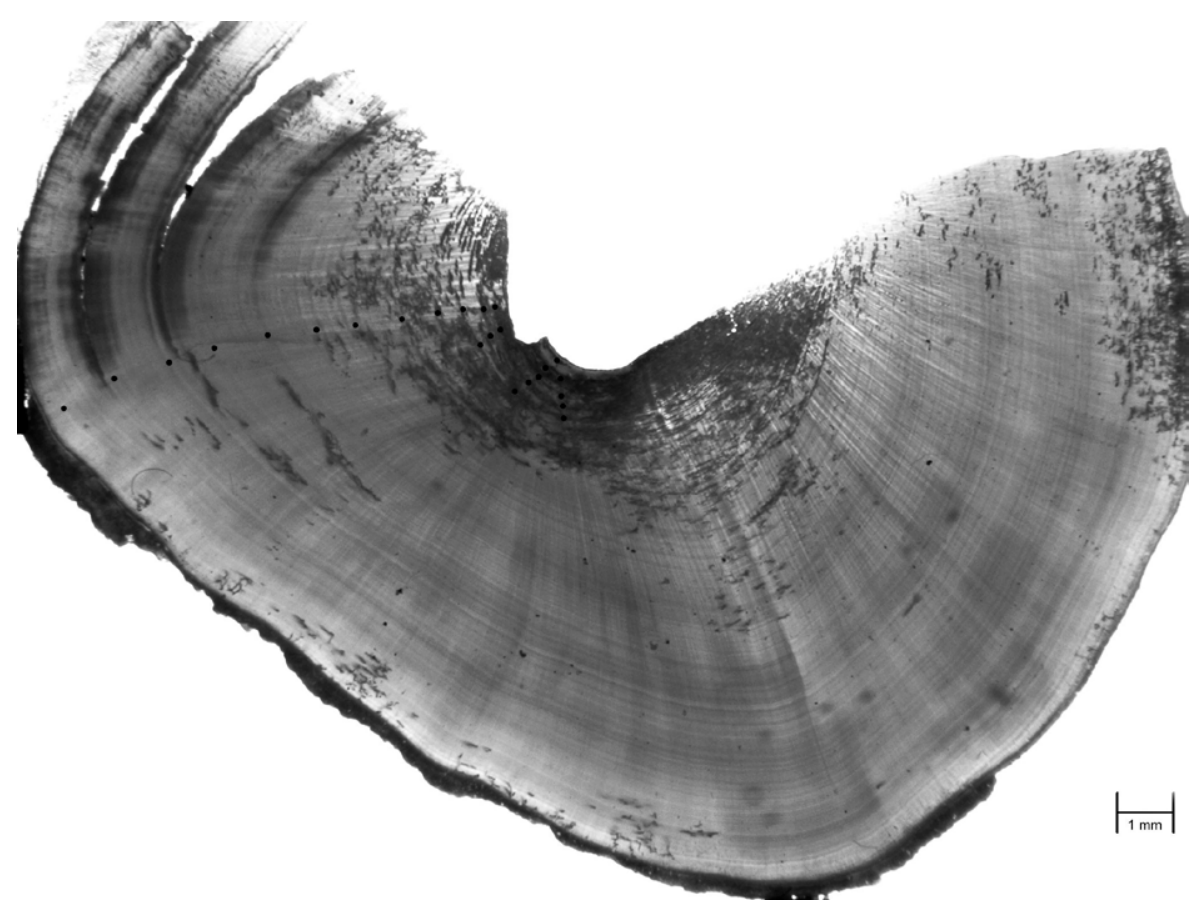

Figure 4. Upper canine teeth of sea lion male, more than 10 years old ( $C d N-11)$. Cross-section. The intercalation of growth bands can be observed. 

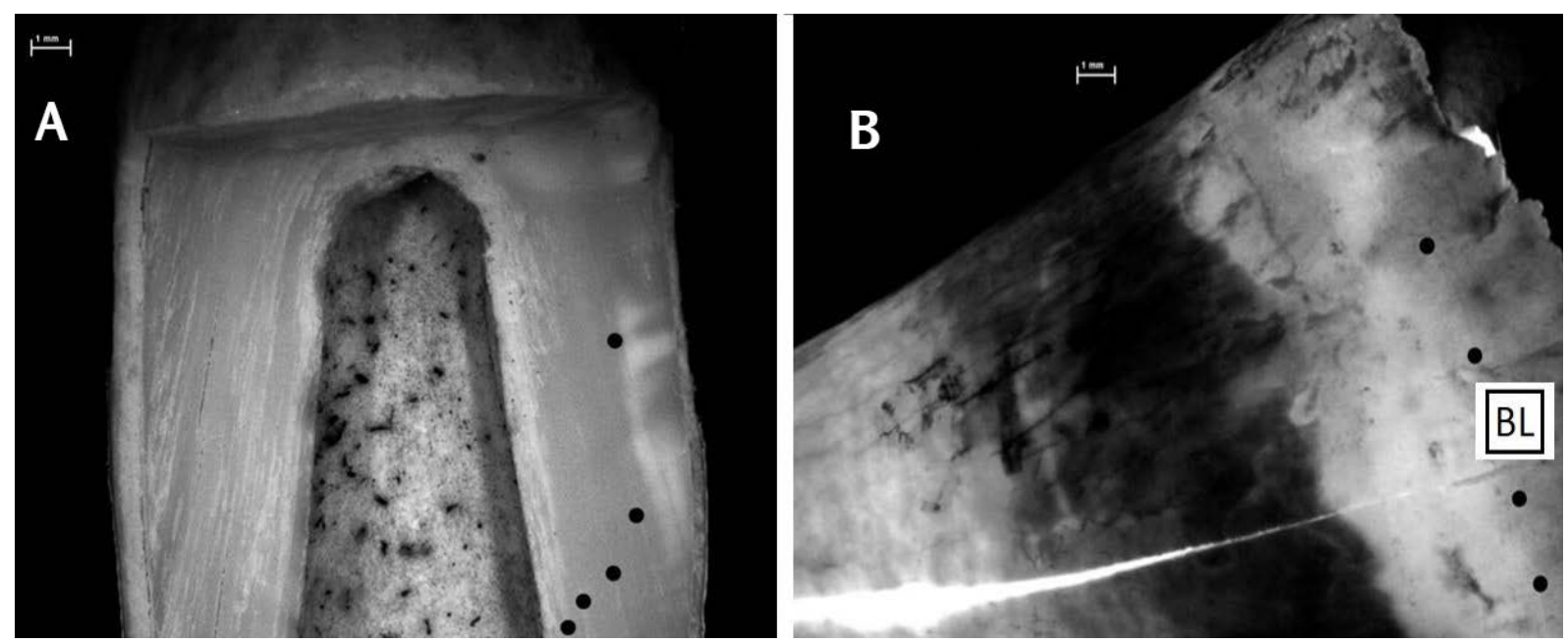

Figure 5. and $C d N$-14. A) Sample $C d N$-17: Longitudinal section (3rd. incisor); B) sample $C d N$-14. Longitudinal section. Neonate (First post canine). Reference: BL (Born Line).

\begin{tabular}{|c|c|c|c|c|c|c|}
\hline $\begin{array}{l}\text { Taxon / } \\
\text { Species }\end{array}$ & Code & Age & Death seasonality & Sex & Sample & $\begin{array}{l}\text { Associated } \\
\text { date (yr. BP) }\end{array}$ \\
\hline \multirow{9}{*}{$\begin{array}{l}\text { Otaria } \\
\text { flavescens }\end{array}$} & $\begin{array}{l}\mathrm{CdN}-01 \\
\mathrm{CdN}-02 \\
\mathrm{CdN}-03 \\
\mathrm{CdN}-04\end{array}$ & $\begin{array}{l}\text { Adult. More than } 11 \text { years } \\
\begin{array}{l}1 \text { month } \\
3 \text { months } \\
3 \text { months }\end{array}\end{array}$ & $\begin{array}{c}- \\
\text { January -February } \\
\text { March } \\
\text { March }\end{array}$ & $\begin{array}{c}\text { Male } \\
\text { Male } \\
\text { Female } \\
\text { Female }\end{array}$ & $\begin{array}{l}\text { 3rd. incisor } \\
\text { Tooth } \\
\text { Tooth } \\
\text { Tooth }\end{array}$ & $1730 \pm 80$ \\
\hline & $\begin{array}{l}\mathrm{CdN}-05 \\
\mathrm{CdN}-06 \\
\mathrm{CdN}-07 \\
\mathrm{CdN}-08 \\
\mathrm{CdN}-09 \\
\mathrm{CdN}-10\end{array}$ & $\begin{array}{l}\text { Adult. More than } 10 \text { years } \\
1 \text { month } \\
\text { More than } 6 \text { years } \\
1 \text { month } \\
\text { ca. } 7 \text { years } \\
\text { More than } 2 \text { years }\end{array}$ & $\begin{array}{c}\text { - } \\
\text { January -February } \\
\text { February-March } \\
\text { January -February } \\
\text { - } \\
\text { March-April }\end{array}$ & $\begin{array}{c}\text { Male } \\
\text { Male } \\
\text { Female } \\
\text { Male } \\
\text { Male } \\
\text { - }\end{array}$ & $\begin{array}{l}\text { 3rd. incisor } \\
\text { Tooth } \\
\text { Tooth } \\
\text { Tooth } \\
\text { Canine } \\
\text { Molar }\end{array}$ & $1220 \pm 80$ \\
\hline & $\mathrm{CdN}-11$ & More than 10 years & January & Male & Canine & - \\
\hline & $\mathrm{CdN}-12$ & 4 years & January -February & Male & Canine & - \\
\hline & $\mathrm{CdN}-13$ & ca. 1 year & January & Male & Tooth & - \\
\hline & $\begin{array}{l}\mathrm{CdN}-16 \\
\mathrm{CdN}-17\end{array}$ & $\begin{array}{l}\text { More than } 1 \text { year } \\
\text { More than } 5 \text { years }\end{array}$ & $\begin{array}{c}\text { April } \\
- \\
\end{array}$ & $\begin{array}{c}\text { Female } \\
\text { Possible Male }\end{array}$ & $\begin{array}{c}\text { Tooth } \\
\text { 3rd. incisor }\end{array}$ & $1290 \pm 50$ \\
\hline & $\mathrm{CdN}-14$ & 1 month & January -February & - & First post canine & $1220 \pm 80$ \\
\hline & $\mathrm{CdN}-15$ & More than 1 year & March & - & Tooth & - \\
\hline & $\mathrm{CdN}-18$ & 2 months & March & Female & Tooth & $1290 \pm 50$ \\
\hline
\end{tabular}

Table 2. Results of death seasonality determination in pinniped teeth.

(March-April). A half-formed opaque layer means the middle of winter (around July) and so on. Sex of the individual was determined by measuring the angle of the crown in canine teeth, or mandibular, or rostral index in lower jaws, or jaw bones (Crespo, 1984). Teeth of juveniles less than three or four years old were not cut given that dentine rings were seen with the naked eye or with the help of a magnifying glass (Figure 3 ).

The three age categories used in this study (neonate, juvenile/sub adult and adult) were defined on the basis of estimates that combined the dental eruption schedule of 
pinnipeds and the dentine layer count. Dental pieces from neonatal preys were from individuals of less than one-year of age. The juvenile/sub adult category comprises to the age bracket between one and up to seven years of age, and adults were individuals of more than seven years of age (Borella, Grandi, Vales, Goodall and Crespo, 2013; Crespo, 1988; Crespo and Pedraza 1991; Crespo et al., 1994; Martinoli, 2015).

\section{Results}

The first results yielded particular seasonality trends within the Cueva del Negro occupation contexts. These indicated that, the pinnipeds were being captured at specific times of the year, during the Austral summer and early autumn, between January and April (Table 2, Figure 6). In regard to age determination, it is interesting to note that most of the samples belonged to neonatal individuals and, to a lesser extent, to juvenile female prey (Figure 6). Only one piece belonged to an adult male whose estimation of the moment of death seemed to correspond to a January date (Figure 6). Between the neonate and juvenile pinnipeds, the death data of the samples was identified across all the months that comprised the aforementioned period (Figure 6). These initial results would seem to suggest two possibilities: that the exploitation of pinnipeds was structured within coastal hunter-gatherer settlements in a seasonal pattern, or that the seasonal exploitation of these resources was simply carried out according to their availability, mainly during the months of January and March, within the framework of the variability of prey consumed by the human groups that occupied the coast throughout the year. These two possibilities will be discussed further below.

\section{Discussion and final considerations}

Based on the preliminary trends observed regarding pinniped exploitation at Cueva del Negro site, we believe it is necessary to increase the number of analyzes of dental samples from other sites, to evaluate and discuss the seasonal nature of coastal occupations in relation perhaps to the existence of mobility circuits during the Late Holocene. In this sense, it would be important to assess whether the results - which point to adult, juvenile and neonatal prey capture during summer season- might respond to the existence of a range of actions that structured the occupation of coastal environments during the summer, opting for the interior during the winter.

Taking into consideration different lines of existing evidence, we believe that this summer/winter split in human hunter-gather economic organization was very likely. In support, studies carried out by Moreno (2003), in relation to dental eruption and bone fusion in guanacos (Lama guanicoe), together with ethnohistorical studies, record the seasonal exploitation of penguins (Spheniscus magellanicus) in archaeological contexts. It is worth mentioning that Cruz $(2006,2007)$, based on taphonomic studies, questions the anthropic origin of part, or all, of the accumulations of penguin bones in the sites analyzed by Moreno. Their interpretations are based on the recognition of the existence of a relationship between human mobility and subsistence. Moreno postulates that mobility could be considered within the framework of the implementation of subsistence strategies aimed at avoiding the depletion of local resources or cushioning the effect of variations in their availability. This author proposes a structure of mobility and subsistence of hunter-gatherer groups from the area, based on the reproductive and migratory cycles of the prey (Moreno, 2003). His model states that during the coldest months of the year, when guanacos were abundant on the coast, exploitation directed towards terrestrial resources was recorded. During the spring and summer, marine resource exploitation would have been a priority, given its greater availability, concentration and predictability due to the breeding season of several species, which 


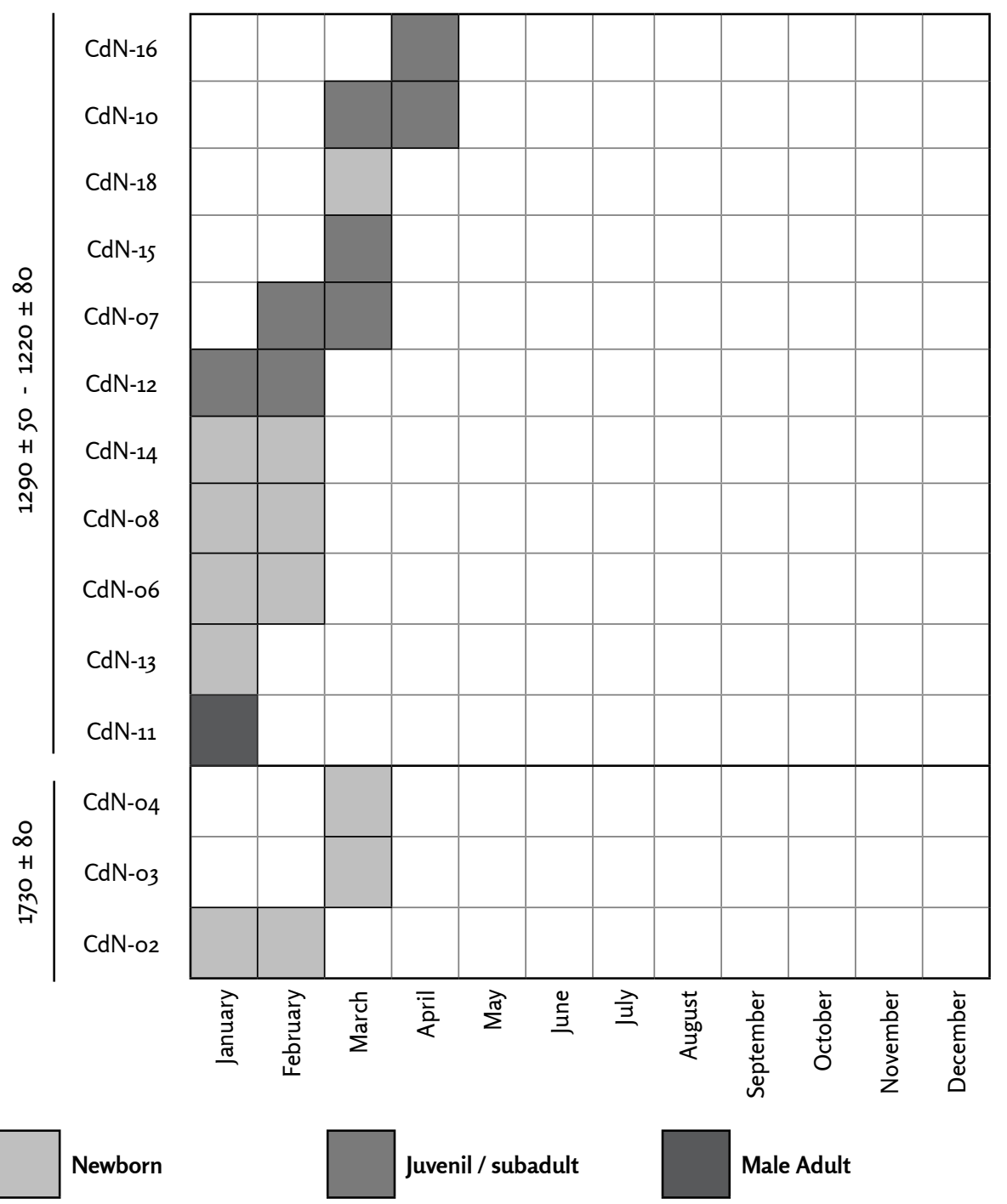

Figure 6. Distribution of pinniped moment of death according to age determination.

included large numbers of pinnipeds (Moreno, 2003). We believe that our preliminary results, presented here, tallies cogently with the Moreno model.

The possible seasonal exploitation of pinnipeds is also consistent with the stable isotope analysis carried out on human bone remains. These isotope studies were undertaken to evaluate the paleodiet of the populations that occupied this area. Results show a clear trend towards mixed diets (Moreno, Zangrando, Tessone, Castro and Panarello, 2011; Zilio, 2015; Zilio, Tessone and Hammond 2018). The authors argue that this trend could be explained by the existence of a seasonal use of the coast, within a framework in which there was complementary exploitation of interior and littoral zones (Moreno et al., 2011; Zilio, 2015; Zilio et al., 2018).

The initial results presented in this paper support the idea of a predominantly summer exploitation of adult, juvenile and neonate pinnipeds, of both sexes, at the Cueva del Negro site, around $c a$. 1,500 years BP. Use of this site might have been desirable due to the existence of breeding colonies relatively close to the site. Therefore, during the summer months there would have been better access to prey from here, possibly as a consequence of pinnipeds low spatial dispersion during this time-lapse (Schiavini, 
1990). It is interesting to contrast these results with those obtained from the South of the Santa Cruz River. In this area, from the study of teeth growth layers and age determinations, it is inferred that the exploitation of pinnipeds would have been carried out in a non-seasonal pattern (Muñoz, Cruz and Cañete Mastrángelo 2016; Pretto, 2016). In order to evaluate more accurately the seasonal nature of the exploitation of pinnipeds, we believe that it will be necessary to increase the number of samples analyzed from coastal spaces and transitional environments located between the marine littoral and the interior plateau of Patagonia.

\section{Acknowledgments}

We appreciate the valuable suggestions of the reviewers. We thank all of those who collaborated in the field and with the laboratory work. Thanks also, to La Plata University, CONICET, FONCYT, and the Agrarian Council of the Province of Santa Cruz and Mario Brozoski Municipal Museum of Puerto Deseado city, for their support in these studies. Our gratitude, to the members of the North Coast of Santa Cruz archeological team. This research was conducted under the remit of the projects "Estudios regionales en el río Deseado para definir los rangos de acción de grupos cazadores recolectores costeros en el marco de la ocupación humana del Holoceno de Patagonia" (N739) and PICT 2016-0404 “Arqueología de la Cuenca inferior del río Deseado: ocupación de refugios rocosos en el marco de la explotación de los recursos costeros". 


\section{References}

» Ambrústolo, P. (2011). Estudio de las estrategias de aprovisionamiento y utilización de los recursos líticos por grupos cazadores recolectores en la Costa Norte de Santa Cruz (Patagonia Argentina). (Unpublished Ph.D. thesis), Universidad Nacional de La Plata, Argentina.

" Ambrústolo, P. and Beretta, M. (2018). Explotación de pinnípedos en abrigos rocosos de la costa norte de Santa Cruz (Patagonia Argentina): tendencias iniciales. Revista Comechingonia. Revista de Arqueología, 22(2), 113-133.

» Ambrústolo, P. and Ciampagna, M. L. (2015). Alero 4 rock shelter, north coast of Deseado estuary (Patagonia, Argentina): Hunter-gatherer mobility strategies during the Late Holocene. Quaternary International, 373, 17-25.

"Ambrústolo, P. and Zubimendi, M. A. (2015). New approaches to the study of huntergatherers of the north coast of Santa Cruz (Argentina): the use of rock shelters. SAA Archaeological Record, 15(3), 16-20.

» Ambrústolo, P., Zubimendi, M. A., Ciampagna, L. and Trola, V. (2011). Alero El Oriental: Evidencias de las primeras ocupaciones de la Costa Norte de Santa Cruz (Patagonia, Argentina). Revista Werken, 14, 9-22.

»Borella, F. (2016). Antes del Faro. La explotación de mamíferos marinos en la localidad de arqueológica Faro San Matías durante el Holoceno tardío (Nordpatagonia, Argentina). In F. Mena (Comp.), Arqueología de Mar a Mar (pp. 295-304). Santiago de Chile: Ediciones CIEP/Ñire Ediciones.

" Borella, F., Grandi, F., Vales, D., Goodall, N. and Crespo, E. (2013). Esquema preliminar de fusión epifisaria en huesos de lobos marinos (Arctocephalus australis y Otaria flavescens), su contribución en los análisis zooarqueológicos. In A. Zangrando, R. Barberena, A. Gil, G. Neme, M. Giardina, L. Luna, C. Otaola, S. Paulides, L. Salgán and A. Tivoli (Eds.), Tendencias teórico-metodológicas y casos de estudio en la arqueología de la Patagonia (pp. 39-51). Buenos Aires: Sociedad Argentina de Antropología (SAA) and Instituto Nacional de Antropología y Pensamiento Latinoamericano (INAPL).

" Bowen, W., Beck, C. and Austin, D. (2009). Pinniped Ecology. In W. Perrin, B. Würsig and J. Thewissen (Eds.), Encyclopedia of marine mammals (pp. 852-861). New York: Academic Press.

"Cartajena, I. F. and Labarca, R. (2007). Patrones históricos de cuereo en lobos marinos: La Evidencia de los Abrigos 1 y 2 de Playa Yámana (Isla Livingston, Antártica Chilena). Magallania, 35(1), 95-105.

»Castro, A., Moreno, E., Andolfo, M., Giménez, R., Peña, C., Mazzitelli, L., Zubimendi, M. A. and Ambrústolo, P. (2003). Análisis distribucionales en la costa de Santa Cruz (Patagonia Argentina): alcances y resultados. Magallania, 31, 69-94.

»Crespo, E. A. (1984). Dimorfismo sexual en los dientes caninos y en los cráneos del lobo marino del sur, Otaria flavescens (Pinnipedia, Otariidae). In Actas de la III Reunión Iberoamericana de conservación y zoología de vertebrados (pp. 245-254). Buenos Aires, Argentina.

"Crespo, E. (1988). Dinámica poblacional del lobo marino del sur Otaria flavescens (Shaw, 180o), en el norte del litoral patagónico. (Unpublished Ph.D. thesis), Universidad de Buenos Aires, Argentina.

"Crespo, E., García, N., Dans, S. and Pedraza, S. (2008a). Arctocephalus australis. Atlas de Sensibilidad Ambiental de la Costa y el Mar Argentino. Mamíferos Marinos. http://atlas. ambiente.gov.ar (Access: May 7th, 2017). 
»Crespo E., García, N., Dans, S., Pedraza, S., Lewis, M. and Campagna, C. (2008b). Otaria flavescens. Atlas de Sensibilidad Ambiental de la Costa y el Mar Argentino. Mamíferos Marinos. http://atlas.ambiente.gov.ar (Access: May 7th, 2017).

»Crespo, E. A. and Pedraza, S. N. (1991). Estado actual y tendencia de la población de lobos marinos de un pelo (Otaria flavescens) en el litoral norpatagónico. Ecología Austral, 1, 87-95.

»Crespo, E. A., Schiavini, A., Pérez Macri, G., Reyes L. and Dans, S. (1994). Estudios sobre determinación de edad de mamíferos marinos del atlántico sudoccidental. In J. Oporto (Ed.), Anales de la Cuarta Reunión de Trabajo de Especialistas en Mamíferos Marinos Acuáticos de América del sur. Centro de Investigaciones y manejo de mamíferos marinos (pp. 31-55). Valdivia: Centro de Investigación y Manejo de Mamíferos Marinos.

»Cruz, I. (2006). Los restos de pingüinos (Spheniscidae) de los sitios de Cabo Blanco (Santa Cruz, Patagonia Argentina). Análisis tafonómico y perspectivas arqueológicas. Intersecciones en Antropología, 7, 15-26.

"Cruz, I. (2007). Avian taphonomy: observations at two Magellanic penguin (Spheniscus magellanicus) breeding colonies and their implications for the fossil record. Journal of Archaeological Science, 34, 1252-1261.

»Cruz, I., Muñoz, S., Ercolano, B., Lemaire, C. R., Pretto, A., Nauto, G. and Moreno, C. (2015). Apostaderos de pinnípedos en Punta Entrada (Santa Cruz, Patagonia Argentina). Explotación Humana e Historia Natural. Magallania, 43(1), 291-308.

» Grandi, M. F, Dans, S. L., García, N. A. and Crespo E. A. (2010). Growth and age at sexual maturity of South American sea lions. Mammalian biology, 75, 427-436.

» Hammond, H. (2015). Sitios concheros en la costa norte de Santa Cruz: su estructura arqueológica y variabilidad espacial en cazadores recolectores Patagónicos. (Unpublished Ph.D. thesis), Universidad Nacional de La Plata, Argentina.

" Lanata, J. L. and Borrero, L. A. (1994). Arqueología sin límites. In J. L. Lanata and L. Borrero (Eds.), Arqueología de Cazadores-Recolectores. Límites, casos y aperturas (pp. 129-143). Arqueología Contemporánea 5, Edición especial. Buenos Aires: Programa de Estudios Prehistóricos.

»Lanata, J. L. and Winograd, A. (1988). Gritos y susurros: aborígenes y lobos marinos en el litoral de la Tierra del Fuego. In Fondo de Promoción de la Cultura (Ed.), Arqueología de las Américas. $45^{\circ}$ Congreso Internacional de Americanistas (pp. 227-246). Bogotá: Fondo de Promoción de la Cultura.

"Laws, R. M. (1962). Age determination of pinnipeds with special reference to growth layers in the teeth. Zeitschrift fur Saugetierkunde, 27, 129-146.

» Legoupil, D. (2003). Cazadores-Recolectores de Ponsonby (Patagonia Austral) y su paleoambiente desde VI al III Milenio A. C. Magallania, 31.

» Loza, C. M., Soibelzon, L. H., Tarnawski, B. A., del Corro, M. E., Negrete, J. and Ciancio, M. (2016). Determinación de edades en Otariidae y Phocidae (Carnivora) sobre piezas dentarias, técnicas alternativas. Revista del Museo de La Plata, 1(1), 39-56.

» Lyman, R. L. (1992). Prehistoric Seal and Sea-Lion Butchering on the Southern Northwest Coast. American Antiquity, 57(2), 246-261.

» Martinoli, M. P. (2015). Procesamiento y consumo de pinnípedos: el caso de las ocupaciones canoeras tempranas del sitio Imiwaia I (Tierra del Fuego, República Argentina). Intersecciones en Antropología, 16, 367-381.

» Molina-Schiller, D. and Pinedo, M. C. (2004). Growth layer patterns in Arctocephalus australis canine teeth: evaluation of techniques for age determination. Latin American Journal of Aquatic Mammals, 3, 107-118. 
» Monks, G. (1981). Seasonality studies. Advances in Archaeological Method and Theory, 4, 177-240.

» Moreno, E. (2003). El uso indígena de la Costa Patagónica Central en el Periodo Tardío. (Unpublished Ph.D. thesis), Universidad Nacional de La Plata, Argentina.

» Moreno, E., Zangrando, F., Tessone, A., Castro, A. and Panarello, H. (2011). Isótopos estables, fauna y tecnología en el estudio de los cazadores-recolectores de la Costa Norte de Santa Cruz. Magallania, 39(1), 265-276.

» Muñoz, S. (2011). Pinniped zooarchaeological studies in Southern Patagonia: current issues and future research agenda. In N. Bicho, J. Haws and L. Davis (Eds.), Trekking the shore: changing coastlines and the antiquity of coastal settlement (pp. 305-332). New York: Springer.

» Muñoz, S., Cruz, I. and Cañete Mastrángelo, D. (2016). Humanos y lobos marinos al sur del río Santa Cruz durante el Holoceno: múltiples líneas de evidencia para el estudio de las relaciones interespecíficas. In F. Mena (Ed.), Arqueología de la Patagonia: de Mar a Mar (pp. 299-309). Santiago de Chile: Ediciones CIEP / Ñire Ediciones.

» Orquera, L. A. and Piana, E. (1999). Arqueología de la Región del Canal Beagle (Tierra del Fuego, República Argentina). Buenos Aires: Sociedad Argentina de Antropología.

» Pretto, A. L. (2016). Determinación de edad y estacionalidad de muerte en dientes caninos de Otaria flavescens y Arctocephalus australis en Punta Entrada (desembocadura del río Santa Cruz, Argentina). Arqueología, 22 Dossier, 231-241.

» Rosas, F. C. W., Haimovici, M. and Pinedo, A. M. (1993). Age and growth of the South American sea lion, Otaria flavescens (Shaw, 180o), in southern Brazil. Journal of Mammalogy, 74(1), 141-147.

» Savelle, J. M., Friesen, T. M. and Lyman, R. L. (1996). Derivation and Application of an Otariid Utility Index. Journal of Archaeological Science, 23, 705-712.

»Schiavini, A. (1990). Estudio de la relación entre el hombre y los pinnípedos en el proceso adaptativo humano del canal Beagle (Tierra del Fuego, Argentina). (Unpublished Ph.D. thesis), Universidad de Buenos Aires, Argentina.

»Schiavini, A. (1993). Los Lobos marinos como recurso para cazadores-recolectores marinos: el caso de Tierra del Fuego. Latin American Antiquity, 4(4), 346-366.

»Schiavini, A., Lima, M. and Batallés, L. M. (1992). Growth structures of maxillary canines of the Southern fur seal (Arctocephalus australis). Marine Mammals Science, 8, 89-93.

» Serrán, M., Centeno, N., Weiler, N. and Gómez Otero, J. (2008). Massive death of pinnipeds 1200 years ago: Taphonomic history of the "Lobos site" (Golfo Nuevo, Patagonia, Argentina). Quaternary International, 183(1), 135-142.

»Svoboda, A. (2013). Método para determinar la estacionalidad de ocupación de sitios arqueológicos de ambientes fluviolacustres de Patagonia a partir de la observación de otolitos de percas. La Zaranda de Ideas. Revista de Jóvenes Investigadores en Arqueología, $9(2), 145-153$.

»Wittmann, T. A, Izzo, C., Doubleday, Z. A., McKenzie, J., Delean, S. and Gillanders, B. M. (2016). Reconstructing climate-growth relations from the teeth of a marine mammal. Marine Biology, 163(4), 1-11.

»Woodborne, S., Hart, K. and Parkington, J. (1995). Seal bones as indicators of the timing and duration of hunter-gatherer coastal visits. Journal of Archaeological Science, 22, 727-740.

»Zilio, L. (2015). Prácticas mortuorias en la Costa Norte de Santa Cruz: arqueología de sociedades cazadoras recolectoras en paisajes costeros de la Patagonia argentina. (Unpublished Ph.D. thesis), Universidad Nacional de La Plata, Argentina. 
" Zilio, L., Tessone, A. and Hammond, H. (2018). Stable isotope ecology and human palaeodiet in the northern coast of Santa Cruz (Argentine Patagonia). International Journal of Osteoarchaeology, 28(3), 305-317.

"Zubimendi, M. A. (2010). Estrategias de uso del espacio por grupos en la Costa Norte de Santa Cruz Cazadores Recolectores y su Interior inmediato. (Unpublished Ph.D. thesis), Universidad Nacional de La Plata, Argentina.

» Zubimendi, M. A., Ambrústolo, P., Beretta, M., Mazzitelli, L., Ciampagna, L., Hammond, H., Zilio, L., Plischuk, M. and Castro, A. (2011). Sitio Cueva del Negro: Un caso de aprovechamiento intensivo de los recursos marinos en la Costa Norte de Santa Cruz (Patagonia Argentina). Revista Estudios Marítimos y Sociales, 4, 51-62.

»Zubimendi, M. A., Ambrústolo, P., Zilio, L. and Castro, A. (2015). Continuity and discontinuity in the human use of the north coast of Santa Cruz (Patagonia Argentina) through its radiocarbon record. Quaternary International, 356, 127-14. 